\title{
Integrative Law Enforcement about Tin Mining Reclamation Responsibility at Bangka Belitung Island.
}

\author{
Dwi Haryadi ${ }^{1, *}$, Darwance ${ }^{2}$, and Reko Dwi Salfutra ${ }^{3}$ \\ ${ }^{1}$ Department of Law, Faculty of Law, Bangka Belitung University - Indonesia \\ ${ }^{2}$ Department of Law, Faculty of Law, Bangka Belitung University - Indonesia \\ ${ }^{3}$ Department of Law, Faculty of Law, Bangka Belitung University - Indonesia
}

\begin{abstract}
Tins mining at Belitung Island had been started since $17^{\text {th }}$ century, since the era of British colonialism, Dutch, Japan invasion until independence era and nowadays, tins exploitation still exists. Tins mining activities make an impact to living environment condition in Belitung island. Hundreds holes of tins exploration called "kolong" (pit) can be found easily. In good mining practice context and mining regulation, tins mining exploitation should be ended with reclamation, so, the impact of environmental damage could be minimize. But, in implementation there are many problem, such as neglect of reclamation obligation, minimum realization, wrong perception about reclamation guarantee, the results of the reclamation that being mined again, and lack of supervisions. This research focused to analyze some of those problems in a integrative law enforcement framework. This research is a qualitative research with primary data and secondary data. The data collection techniques are through literature study and interviews with related stakeholder, and also do observations at reclamation sites. This research show that reclamation responsibilities Implementation's problems caused by many factors, and through integrative law enforcement approach focused on three study's components, which is legal substance, legal structure components, and legal culture components can encourage tins mining reclamation at Belitung Island in line with good mining practice principle and sustainable development with environmentally conception.
\end{abstract}

\section{Introduction}

Living environment versus mining are two different issues meet at one point. Both are always in two different ways. For the environment activists, mining activities $100 \%$ can make environmental damage and hard to accept green mining concept. In the opposite, for mining companies, minerals are economical potential that should be exploited and good mining practice become a solution to its environmental impact. International world, through 
Stockholm Declaration 1972 and The Rio de Janeiro Declaration on Environment and Development 1992 seeks to overcome environmental crisis over the impact of development through sustainable development with environmentally conception (in Hardjosoemantri, 2005). Even the concept in few decades until nowadays unable or failed to manage resource wisely, so that [1] suggest "ecological sustainability".

Belitung Island as a part of the largest tin-producing province in Indonesia that had been exploited since $18^{\text {th }}$ century [14], also experiencing an environmental crisis as well as other mining areas. [12] showed the area of ex-mining land on Belitung Island is 45.675 ha, and the "kolong" area is 3.160 ha. From the criminality perspective, environmental damage was also triggered by illegal mining rampant activities and also weak environmental law awareness has become a phenomenon since 1991 until now [2][3]. Environmental degradation is also become a direct impact of the characteristic of tin governance which is hegemonic and capitalistic. Political economy studies conducted by [5] found out that capitalistic character is seen by the capital domination, transnational economy, economic inequality and inheritance of problems in the form of environmental damage, social conflicts, moral decadence, behavior changes and crimes.

Behind all the facts, data and various studies that have been done above, tin mining activities continue and simultaneously environmental degradation also continues on Belitung Island. In the concept of environmental mining, there is an obligation int the form of reclamation. But, so far, the implementation of reclamation has not been able to show optimal results, even become problematic itself in tin mining problems. Therefore, one of the strategic issues in the Regional Medium-Term Development Plans (RPJMD) Bangka Belitung Islands in 2017-2022 is an environmental issue.

Speaking about tin mining companies reclamation responsibilities problematic, then we discuss the issue of law mining enforcement as well as environmental law enforcement. Some regulations have clearly regulated reclamation obligations. In Act No. 4 of 2009 concerning Minerals and Coal, it has been stipulated that in every application for mining permits must be accompanied by reclamation planning, including the guarantee of reclamation. As a derivative, Government Regulation Number 78 of 2010 concerning Reclamation and Post-mining also confirms that reclamation obligations are carried out by permit holders. Even before conducting exploration activities, it is compulsory to prepare a reclamation plan based on environmental documents, and the reclamation plan must be included in the work plan and exploration budget. More technically, in the Regulation of the Minister of Energy and Mineral Resources Nmber 7 of 2014 concerning Implementation of Reclamation and Post Mining in Mineral and Coal Mining Business Activities regulates the technical guidelines for the implementation of reclamation from planning to the reclamation stage.

Law enforcement or the implementation of various legal regulations above regarding the obligation of reclamation of former tin mining land is in fact influenced by many factors so that it is not effective. Some of these factors, among others, are the neglect of reclamation obligations, the realization of minimal reclamation responsibilities, the misperception of reclamation guarantee funds, the results of reclamation being mined again, and lack of supervision. 
The implementation of reclamation that has not been optimal with the various problems above requires an integrated law enforcement between the components of the legal substance, legal structure components and components of legal culture. All this time, each component has its own weaknesses and runs each other so that reclamation is not optimal, even the mine becomes a nightmare for the Belitung environment. As stated by Rusli Rahman (2009), the problem of tin is like rice that has become porridge. Tin, legal and illegal mines inevitably have and continue to create hundreds of "kolong" and environmental degradation, while reclamation efforts are so slow. Lamenting damage and condemning mining will not solve the problem, but there is must be an acceleration and strategic effort to ensure that reclamation is carried out properly. This research tries to map law enforcement issues to the responsibility of reclamation and formulate an integrative solution.

\section{Research Methods}

This paper is obtained from the results of quantitative research in the domain of socio legal research which aims to study the law of the state of society. The approach uses social legal approach to understand the law in the context of society. Then there is a conceptual approach, and a act approach (normative approach) (Marzuki, 2005). Data includes primary data and secondary data. Primary data in legal research can be seen from the legal behavior of citizens [9]. Determination of the informants was done through purposive sampling, namely the technique of sampling data sources with certain considerations $[13,10]$. The speakers included Occupational Health and Safety and The Environment (K3LH) PT. Timah (Persero) Tbk, PT. Timah (Persero) Tbk Unit Office of Belitung, the Branch Office of the Energy and Mineral Resources Department (ESDM) of Belitung Regency and East Belitung Regency, Environmental Offices of Belitung Regency and East Belitung Regency, Village-Owned Busness Entity (BUMDes) involved in reclamation, and Belitung Nature Lovers Association (GAPABEL). Secondary data includes various regulations, journals and related research results. Data collection techniques are carried out with documentation, field observations, and in-depth interviews, as well as literature studies. Data were analyzed using an interactive model proposed by [8] which included 3 (three) activities, namely data reduction, data presentation and conclusion or verification.

\section{Research Results and Discussion}

\subsection{Reclamation Obligations as Regulatory Demands}

Reclamation is an important instrument in creating good mining practice, because it is a manifestation of environmentally conception's mining. Reclamation between mining interests and environmental interests. This means that if the reclamation obligation is not carried out optimally, then the last bastion of environmentally-friendly mining is a dream. The obligation of reclamation as a form of responsibility for mining activities should not be negotiable. In terms of regulation, from the constitution to technical regulations, 
reclamation is required. The 1945 Constitution through Article 33 paragraph (3) and paragraph (4) has outlined that the governance of natural resources is controlled by the state for the greatest prosperity of the people, and as part of the national economy is organized based on economic democracy with the principles of togetherness, efficiency with justice, sustainability, environmental insight, independence, and by maintaining the balance of progress and unity of the national economy [6].

Then based on Act No. 4 of 2009 concerning Mineral and Coal also explicitly requires reclamation, even reclamation planning and reclamation guarantees are a requirement in applying for mining permits. In Government Regulation Number 78 of 2010 concerning Reclamation and Post Mining in Article 2 it is stipulated that IUP and IUPK holders are obliged to carry out reclamation by fulfilling 3 (three) principles, namely (1) protection and management of the mining environment; (2) occupational safety and health; and (3) mineral and coal conservation. Based on Article 29, there are obligations for reclamation guarantees both at the exploration and production operations stages, and Article 32 also confirms that the Placement of Reclamation Guarantee does not eliminate the obligation of IUP and IUPK holders to carry out reclamation. Because all this time there is a mistaken perception from permit holders that after payment of reclamation guarantees they are released from their responsibilities and the reclamation obligation goes to the local government.

This Government Regulation also regulates administrative sanctions if various reclamation obligations are not carried out. Article 50 states that there are 3 types of administrative sanctions that can be given, namely written warnings; temporary suspension of activities; and / or Revocation of Mining License (IUP), Special Mining Permit (IUPK), or Space Utilization Permit (IPR). Then for those who are subjected to administrative sanctions in the form of license revocation, they do not eliminate their obligation to continue reclamation. Furthermore, regulations that become technical guidelines related to reclamation obligations are Regulation of the Minister of Energy and Mineral Resources Number 7 of 2014 concerning the implementation of reclamation and post mining in mineral and coal mining business activities. At the regional level, there is a Regional Regulation of the Province of Bangka Belitung Islands Number 7 of 2014 concerning Management of Mineral Mining, including tin as an important commodity of this province. Article 4, for example, states that the scope of the management of mineral mining includes reclamation and post-mining. So explain that reclamation obligations are regulatory demands ranging from the constitution to regional regulations.

\subsection{Half-hearted Reclamation Implementation}

Although reclamation is an obligation even the demands of the regulation with a set of sanctions, the implementation has not shown maximum results on Belitung Island. Based on observations to several reclamation areas in Belitung and East Belitung regencies, although they cannot represent all tin mining areas covering hundreds of thousands of hectares, it is seen that reclamation is not yet optimal. This is indicated by the existence of post-mining areas that have not been reclaimed, reclamation plants that are not growing and the reclamation area in the form of a pit of water that cannot be planted. This fact turns out 
to be in line with the realization of reclamation by PT Timah (Persero) Tbk as a StateOwned Enterprise, locally known as BUMN, that is also obliged to reclaim. Based on the data in Table 1 about the data on reclamation realization on Belitung Island, it is still far from what was planned. Even from annually's target, no one has reached the target. There is no annually achievement that reaches 50 percent, a maximum of only reached 25 percent in 2016 .

Table. 1. Belitung Island Reclamation Data 2015-2017

\begin{tabular}{|l|l|l|l|c|c|c|}
\hline \multirow{2}{*}{ No } & \multirow{2}{*}{ Years } & \multirow{2}{*}{ Plan (Ha) } & \multicolumn{2}{|c|}{ Realization (Ha) } & \multirow{2}{*}{ Type of Plant } & $\begin{array}{c}\text { Planting } \\
\text { Distance(m) }\end{array}$ \\
\cline { 4 - 5 } & & Belitung & $\begin{array}{c}\text { East } \\
\text { Belitung }\end{array}$ & & \\
\hline 1 & 2015 & 400 & - & 78,14 & Akasia mangium & $4 \times 4$ \\
\hline 2 & 2016 & 400 & 22,89 & 27,35 & Sengon laut & $4 \times 4$ \\
\hline 3 & 2017 & 400 & 10,08 & 19,88 & Sengon laut & $4 \times 4$ \\
\hline \multicolumn{2}{|c|}{ Jumlah } & & 32,97 & 125,37 & & \\
\hline
\end{tabular}

Source : PT. Timah (Persero) Tbk, 2018

Based on interviews with various stakeholders related to reclamation, there were several issues in its implementation. According to Benny Pahala Hutahaean as Head of the K3LH Division of PT. Timah (Persero) Tbk, the obstacle encountered was that there were still people who refused to be reclaimed because they believed that the land would be owned by PT Timah (Persero) Tbk or the state. Even though it is clear that the rules will be returned only through the government mechanism first. Another problem is if the land is still in conflict such as ownership with certificate of evidence by individuals, then there must be an approach first. Then there is the reclamation area which is mined again by the people. But in addition to some of these issues, efforts to encourage the success of reclamation are also carried out, such as internal and external supervision, maximum fertilization due to infertile ex-mining land, reclamation with productive and economical crops, and involving the community through BUMDes, and synergizing with agencies others like the Police. While the Head of K3LH, Belitung Tin Unit, Rahardian said that for reclamation involving partners, it required that the workforce be half of the partners and half of them from the local community. Hopefully there is ongoing supervision. Unfortunately, not many people want to be involved because of inadequate income.

The viewpoint of the reclamation issue from the perspective of the Belitung Environmental Service, Ubaidilah as the Head of the Office said that there is a wrong perception when they had deposited the reclamation guarantee and then does not do the reclamation. In terms of regulation, the actual reclamation guarantee is actually more stringent, which is made in the Prepare and Organized Workplan Budget (RKAB) for activities. For supervision from the provincial and central ESDM we should also be involved, but so far there is no. So we do not know the progress of reclamation that has been running and its success. The issue of reclamation in the IUP is actually already clear who is responsible. Precisely what is a problem and needs mutual attention is those outside the IUP that illegal miners do.

While Arbai, as the Head of the Environmental Office of East Belitung said that in the perspective of environmental protection, we always require reclamation in the AMDAL document for the issuance of tin IUP. The success of reclamation can be said to be only 60 
percent. The reason is because it is not easy with a number of obstacles such as land conflicts, not easy to grow and mined back by the community, also depends on the commitment of the company itself. PT Timah (Persero) Tbk is committed because it is a SOE, although it still needs to be improved. But the private sector that has not seen its reclamation yet. The wrong perception that reclamation guarantees that have been paid and not reclaimed also occurred here. Another obstacle is policy changes, where mining authority is withdrawn to the province, making it difficult to carry out supervision and coordination.

Regarding the reclamation of tin mines in Belitung, The Chairman of the GAPABEL, Pifin believes that only 10 percent are reclaimed from the existing IUP area. PT Timah (Persero) Tbk itself shows a lot of reclamation signs, but as we see the areas not all reclaimed. Then the plants used are neither productive nor economical so that it is rather difficult to involve the community for their sources of income. GAPABEL itself has never been involved in reclamation and if there is any we will refuse, let the company fix what they have damaged, we do supervision. While the issue of reclamation is being mined again by the people, it needs awareness from the community itself. So far only reclamation has been seen from the IUP of PT. Timah (Perseo) Tbk, while the private sector has never seen it.

While from the Belitung Department of Energy and Mineral Resources, the head of his office said that regarding the reclamation supervision, considering that according to the current rules all authority is centralized in the province, usually they go directly to the areas to see and assess reclamation. We ourselves have limitations and human resources, there are only branch heads who supervise the Head of the Mining Section and the Head of the Electricity Section, as well as a Head of Administration Section. Not much different from Belitung, according to the Head of the East Belitung Energy and Mineral Resources Office, Solihin, who was accompanied by the Head of the Mining Section, Mr. Yanprid said that after the Act 23 of 2014 where mining authority was under provincial control, organizational structure still had problems. Regarding to the reclamation in the district only limited to accompanying teams from the province. Sometimes a team of assessors comes even we don't know. Our current task is limited to issuing a Production Certificate (SKP) for shipping between regions. So we have already created a service branch but the authority has not been fully granted. Even though we are the most knowledgeable about the condition of the area.

\subsection{Integrative Law Enforcement For Reclamation Responsibilities}

According to Barda Nawawi Arief (2011) the law enforcement system must be seen integrally, which is a unity of various sub-systems (components) consisting of components "legal substance", "legal structure" and "culture" law (legal culture). That is, in law enforcement for the reclamation's responsibility requires the integration of these three components.

First, the component of legal substance. In terms of regulation, reclamation obligations are regulated starting from the Act of Law on Minerals and Coal, and their derivatives in 
Government Regulations, as well as technical guidelines through Ministerial Regulations, including regulations in the regions through the Bangka Belitung Islands Provincial Regulation. That is, what is needed now is the commitment of the mining company to implement reclamation according to the rules and its supervision by a cross-sector assessment team to ensure that reclamation is carried out properly and correctly. Seeing the fact that regulation has not been implemented properly, one of them is because weak administrative sanctions need to be considered in the form of other heavier sanctions to encourage companies to comply. Likewise the importance of regulating how to reclamate outside the IUP or illegal mining, so how post mining still requires reclamation and this is the responsibility of the state. In addition, the future regulation must be made as good as possible which takes into account many aspects, so that it is not easy to change and should be able to facilitate coordination rather than complicate it.

Second, the legal structure component. The legal structure in this context is all parties related to reclamation. Mining companies, whether PT Timah (Persero) Tbk as SOE or the private sector must fulfill their obligations. There must be a commitment to environmental care and corporate responsibility for the tin mining activities that have been carried out and have an impact on the environment in Belitung. Go Green should not only be a company tagline, but do a maximum reclamation. Involve local communities and BUMDes as partners with beneficial cooperation patterns for the community so that reclamation promises economically. Then for the Environmental Service must also be maximal in supervising the planning and implementation of reclamation in accordance with its authority considering the location of the mine and reclamation in the region itself. While for the ESDM Office Branch itself, organizational problems and authority must be resolved and in the future the authority must be given to the official branch in the regency regarding reclamation. The provincial government and the central ESDM itself must also involve the district government where the reclamation location is in conducting reclamation assessments so that objective cross-sector monitoring can be carried out.

Third, the component of legal culture. Legal culture is related to the culture / behavior of legal awareness, be it the community or stakeholders themselves. In this component, green culture must be cultivated at the level of the community and the mining corporation and the government itself. Green culture must be a commitment and a joint movement, not just symbolic and ceremonial, but must be sustainable. Tin mines that have inherited environmental damage need reclamation based on commitment and mutual awareness.

\section{Conclusions}

Based on study above, it can be concluded that the tin mining reclamation efforts on Belitung Island have not gone well as seen from the achievements and successes. There are several obstacles faced, such as the reclamation area which is mined back by the community, the reclamation program that has not yet been economically promising for the community, the reclamation is not easy because the ex-mine land is not fertile anymore, there is land conflict, and others. Therefore, the implementation of reclamation as a corporate responsibility as part of law enforcement requires an integrative approach, 
whether it is reforming the substance or regulation components, structural components, or legal cultural components. Through efforts to improve these three components, it is hoped that in the future the responsibility of this reclamation can be carried out more effectively and an environmentally friendly mining can be achieved.

\section{References}

1. A.Sonny Keraf, Etika Lingkungan Hidup, (Kompas, Jakarta, 2010)

2. Dwi Haryadi, Memahami Hukum Kritis, (UBBPress, Pangkalpinang, 2009)

3. Dwi Haryadi, Audit Lingkungan untuk Babel Lestari, (Prosiding Seminar Nasional BKS FH PTN Wilayah Barat. Bangka Tengah, 2014)

4. Faktor Kriminogen Illegal Mining Timah di Bangka Belitung, (Jurnal MasalahMasalah Hukum FH UNDIP. Semarang, 2015)

5. Ibrahim, Sengkarut Timah dan Gagapnya Ideologi Pancasila, (Imperium, Yogyakarta, 2013)

6. Jimly Asshiddiqie, Green Constitution, (RajawaliPress, Jakarta, 2009)

7. Kusnadi Hardjasoemantri, Hukum Tata Lingkungan, (UGMPress, Yogyakarta, 2005)

8. Mattew B. Miles \& A. Michael Huberman, Analisis Data Kualitatif, (UIPress, Jakarta, 1992)

9. Mukti Fajar ND dan Yulianto Achmad, Dualisme Penelitian Hukum Normatif dan Empiris, (Yogyakarya, 2010)

10. Muslan Abdurrahman, Sosiologi dan Metode Penelitian Hukum, (UMM Press, Malang, 2009)

11. Rusli Rahman, Redupnya Hati Nurani, (Aksara Sastra, Yogyakarta, 2009)

12. Sukarman dan Gani, Lahan Bekas Tambang Timah di Pulau Bangka dan Belitung, Indonesia dan Kesesuaiannya untuk Komoditas Pertanian, (Jurnal Tanah dan Iklim, Vol. 41, No. 2, Desember 2017)

13. Sugiyono, Metode Penelitian Kuantitatif, Kualitatif dan R\&D, (Alfabeta, Bandung, 2009)

14. Sutedjo Sujitno, Dampak Kehadiran Timah Indonesia Sepanjang Sejarah, (Cempaka Publishing, Jakarta, 1996) 